VioletTa PRUSińSKA

ORCID 0000-0002-1213-9363

JAN STRUGAREK

ORCID 0000-0002-5563-8904

JAKUB WIECZOREK

ORCID 0000-0003-1576-6503

Uniwersytet im. Adama Mickiewicza

$w$ Poznaniu

\title{
WYKORZYSTANIE GIER KOMPUTEROWYCH Z CZUJNIKIEM RUCHU TYPU KINECT W ĆWICZENIACH KORYGUJĄCYCH WADY POSTAWY
}

\begin{abstract}
AвSTRACT. Prusińska Violetta, Strugarek Jan, Wieczorek Jakub, Wykorzystanie gier komputerowych z czujnikiem ruchu typu Kinect w ćwiczeniach korygujacych wady postawy [The Use of Computer Games with a Kinect Type Motion Sensor in Exercises Correcting Posture Defects]. Studia Edukacyjne nr 60, 2021, Poznań 2021, pp. 279-292. Adam Mickiewicz University Press. ISSN 1233-6688. DOI: 10.14746/ se.2021.60.15
\end{abstract}

The development of science and technology brings about many advantages for human beings, yet it also creates a risk for their health and correct growth, including problems with right posture among children. The fast pace of life, an increasing number of tasks in- and outside of school, lack of physical activity, bad dietary habits and permanent compression of vertebrae are the main factors responsible for posture problems among child and teenager groups. The ages between 7 and 10 seem to be a critical period for forming the body position and it is connected with changing children's daily learning routine (from free and loose activity to a few-hour sitting position at school). In effect, about $60 \%$ of children suffer from postural problems. This percentage has a rising tendency as such problems increase with age. The prevention and treatment of consequent disorders is based e.g. on physical exercise during corrective gymnastic classes, where a number of new technology solutions to improve standard and quality of such classes are used, e.g. motion sensors (Microsoft Kinect). This article connects corrective exercises with motion-control-based computer games. This approach uses the natural interest of children for interactive games to improve their engagement in corrective exercises. This new form of health-related activity packed in a "computer driven case" is a real chance to make corrective exercises more children-friendly and thus to stimulate children's motivation to actively participate in them.

Key words: faulty posture, posture correction, interactive motion games, Kinect motion sensors 
Prawidłowa postawa ciała jest bez wątpienia jednym z najważniejszych elementów, zapewniających właściwe funkcjonowanie organizmu człowieka. Według jednej z definicji, jest „....wskaźnikiem mechanicznej wydolności zmysłu kinetycznego, równowagi mięśniowej i koordynacji nerwowo-mięśniowej"1. Przez całe życie człowiek podlega działaniu czynników mogących zaburzyć jego sylwetkę, do których zalicza się między innymi nieprawidłowe napięcie mięśniowe, otyłość i nadwagę, wykonywaną pracę fizyczną, złe ułożenie ciała podczas snu i wypoczynku, jak również podleganie oddziaływaniu nadmiernych sił zewnętrznych. Należy jednak pamiętać, że postawa ciała kształtuje się głównie w początkowych latach życia człowieka. U dzieci i młodzieży układ szkieletowy oraz mięśniowy jest bardziej plastyczny i podatny na czynniki zaburzające prawidłowy rozwój, niż ma to miejscu u dorosłych. $Z$ tej przyczyny nieprawidłowa postawa ciała stanowi problem zdrowotny, szczególnie istotny dla młodych osobników. Zdiagnozowane wady postawy u dzieci w wieku 7 15 lat stanowią od $65 \%^{2}$ do ponad $90 \%{ }^{3}$ ogółu badanych populacji.

Środowiska medyczne i pokrewne poszukują w związku z tym nowych rozwiązań i sposobów, mających na celu zapobieganie pojawieniu się wad postawy, a także ich korekcji w sytuacji kiedy wady te faktycznie zaistnieją. Wraz z szybko postępującym w ostatnich dziesięcioleciach rozwojem cywilizacyjnym i technicznym podejmowane są próby wykorzystania nowych zdobyczy technologicznych do leczenia rozmaitych schorzeń i urazów. Podobnie wzbogaca się nowymi technologiami terapię wad postawy - na przykład poprzez wykorzystanie komputerowej diagnostyki postawy ciała, wielowymiarowe obrazowanie zmienionych odcinków ciała (m.in. metodą Mora4D), wykorzystanie nowoczesnych czujników do kontroli odchyleń somatycznych i tym podobnych.

Doceniając rolę nowoczesnych rozwiązań technicznych w obszarze poprawy stanu zdrowia człowieka, a także uwzględniając istotny problem wad postawy wśród dzieci i młodzieży, podjęte działania koncentrowały się na próbie wzbogacenia terapii wad postawy nowymi zdobyczami technologicznymi.

\section{Cel badań, hipotezy i procedury badawcze}

Przeprowadzone w ostatnich latach badania jednoznacznie dowodzą, że korzystanie z komputera wymienia się jako czynność, której dzieci i młodzież

\footnotetext{
${ }^{1}$ A. Zwierzchowska, K. Gawlik, Korektywa dzieci i młodzieży z dysfunkcjami wzroku lub stuchu, Katowice 2006, s. 71.

${ }^{2}$ W. Hagner, D. Bąk, M. Hagner-Derengowska, Changes in body posture in children between the 10th and 13th years of age, Pol. Ann. Med., 2011, 18, 1, s. 76-81.

${ }^{3}$ R. Janiszewska i wsp., Nieprawidłowości postawy ciała u dzieci 6-12-letnich - uczniów szkót podstawowych z Radomia - badania pilotażowe, Probl. Hig. Epidemiol., 2009, 90(3), s. 342-346.
} 
poświęcają bardzo dużą część wolnego czasu. Wskazuje się przy tym na gry komputerowe, stanowiące jedną z najbardziej ulubionych postaci rozrywki $\mathrm{w}$ tej grupie wiekowej ${ }^{4}$. Podstawowym założeniem projektu był fakt coraz większej popularności gier wykorzystujących różne rodzaje czujników ruchu, w tym czujnika Kinect - produktu firmy Microsoft. Warto zaznaczyć, że czujnik ten $\mathrm{z}$ powodzeniem wykorzystywany jest $\mathrm{w}$ badaniach nad dokładnością czasową i przestrzenną ruchów osób z rozmaitymi schorzeniami ${ }^{5}$.

Jako główny cel badawczy projektu przyjęto zatem określenie, czy czujnik ruchu typu Kinect można wykorzystać w procesie korekcji wad postawy u dzieci i młodzieży. Dodatkowym celem było stwierdzenie, czy ćwiczenia z udziałem czujnika Kinect są dla uczniów dodatkową, bezpośrednią motywacją do podejmowania samodzielnych, spontanicznych ćwiczeń. Inaczej mówiąc - czy elementy interaktywnych gier ruchowych z wykorzystaniem czujnika ruchu typu Kinect można zastosować podczas ćwiczeń korygujących wady postawy. Pozytywne odpowiedzi na tak sformułowane cele pozwoliłyby pozyskać nowatorską formułę ćwiczeń korekcyjnych, bazującą na wysokiej motywacji ćwiczących do gry i dużej atrakcyjności, przy jednoczesnym zachowaniu ścisłej kontroli wykonywanych podczas gry aktów ruchowych, wynikającej z właściwości czujnika Kinect.

W celu zrealizowania tak sformułowanego celu, procedurę badawczą podzielono na kilka etapów. Etap pierwszy koncentrował się na przygotowaniu aplikacji komputerowej, współpracującej z czujnikiem Kinect. Aplikacja ta od strony technicznej (opracowanie algorytmu, oprawy graficznej, funkcjonalności itp.) przygotowana została przez zespół naukowców Poznańskiego Centrum Superkomputerowo-Sieciowego, pod przewodnictwem mgra inż. Michała Kosiedowskiego. Natomiast treść aplikacji (rodzaj ruchów kontrolowanych przez aplikację, ich odpowiedni dobór itp.) przygotowana została przez fizjoterapeutów i nauczycieli wychowania fizycznego pracujących w Szkole Wychowania Fizycznego i Sportu Uniwersytetu im. Adama Mickiewicza w Poznaniu. Ostatecznie powstała aplikacja, która rozpoczynała się panelem menu głównego. $Z$ tego poziomu aplikacji można było (oprócz dodatkowych opcji związanych z ustawieniami) utworzyć indywidualny profil ćwiczącej osoby, co pozwalało zapisać personalne osiągnięcia ucznia. Następnie, aplikacja pozwalała na przejście do właściwych sześciu różnych ćwiczeń ukierunkowanych na konkretną wadę postawy - plecy okrągłe. Przygotowane ćwiczenia $\mathrm{w}$ pierwszej kolejności pokazywane były na ekranie przez postać komputerową - awatar. Z kolei, ćwiczący miał możliwość wykonania

\footnotetext{
${ }^{4}$ A. Wojtyła i wsp., Aktywność fizyczna młodzieży gimnazjalnej w Polsce, Problemy Higieny i Epidemiologii, 2011, 92(2).

${ }^{5}$ E. Mikołajewska, D. Mikołajewski, Wykorzystanie robotów rehabilitacyjnych do usprawniania, Niepełnosprawność - zagadnienia, problemy, rozwiązania, 2013, 4(9), 38.
} 
kilku ruchów treningowych, po których podejmowano właściwą, ocenianą przez aplikację próbę. Uzyskany wynik punktowy, wyrażany w otwartej skali, zależał od zbieżności czasowej i przestrzennej oraz dokładności wykonywanych ruchów, porównywanych ze wzorem ruchu prezentowanym przez awatar. Te parametry były rozpoznawane i monitorowane przez czujnik ruchu Kinect.

Po opracowaniu tak działającej aplikacji, wdrożony został kolejny etap prac. Polegał on na przeprowadzeniu badań pilotażowych, obrazujących funkcjonowanie aplikacji w praktyce. Ta część realizacji projektu rozpoczęła się od nawiązania współpracy z kierownictwem Szkoły Podstawowej nr 1, mieszczącej się przy ul. Hezjoda 152 w Poznaniu. Po akceptacji planu działań przez dyrekcję, dalsza procedura badawcza przebiegała w następujący sposób.

W pierwszej fazie działań nawiązano kontakt z pielęgniarką szkolną, która zaproponowała listę uczniów spełniających kryteria przynależności do grupy badawczej. Głównym kryterium było pojawiające się u uczniów zaburzenie (plecy okrągłe) w zakresie postawy ciała, zaobserwowane w karcie zdrowia ucznia podczas badań przesiewowych. Drugim kryterium był wiek uczniów, mieszczący się w przedziale 8 - 10 lat.

Następnie zorganizowano spotkanie z rodzicami wspomnianych dzieci, podczas którego zaprezentowano roboczą wersję aplikacji wykorzystującej czujnik Kinect oraz omówiono założenia projektu. Rodzice zobowiązali się do dostarczenia pisemnej zgody na udział ich dzieci w badaniach. Do badań przystąpiło ostatecznie 42 dzieci z klas II i III. Za pomocą specjalnie przygotowanej karty diagnostycznej dokonano szczegółowego badania uczniów, które obejmowało pomiar masy ciała, wzrostu, a także ocenę sylwetki na podstawie metody punktowania według Kasperczyka ${ }^{6}$ oraz pomiary kątów krzywizn kręgosłupa inklinometrem. Po zakończeniu tej części badań wyłoniono ostateczną grupę uczniów do dalszej części badań. Wykluczono dzieci z klas niższych niż II i III, głównie ze względu na trudności z jasnym zdiagnozowaniem $w$ tej grupie charakterystycznych cech wad postawy. Ostatecznie po wspomnianej weryfikacji do badań wybrano 28 dzieci.

Tę wybraną grupę uczniów poddano próbie, opartej na testowaniu opisanej wcześniej aplikacji złożonej z elementów gry interaktywnej. Sposób i dokładność wykonania poszczególnych ćwiczeń była obserwowana i weryfikowana przez zespół oceniający. Składał się on z trzech specjalistów fizjoterapii i wychowania fizycznego (arbitrów), obserwujących ćwiczącego z trzech różnych punktów pomieszczenia badawczego. Zadaniem tych osób była ocena wykonania poprawnie poszczególnych ćwiczeń oraz ich zgodność

${ }^{6}$ T. Kasperczyk, Wady postawy ciata - diagnostyka i leczenie, Kraków 2001. 
ze wzorcem (awatarem), zarówno w kontekście czasowym jak i przestrzennym. Każdy arbiter niezależnie oceniał w skali 10-stopniowej parametry jakościowe (poprawność) i ilościowe (tempo i zgodność ze wzorcem) wykonywanego przez badanego ćwiczenia. Wyniki naliczane przez czujnik Kinect uszeregowano w czterech przedziałach. W pierwszym znalazły się rezultaty odpowiadające 75 - 100\% maksymalnego wyniku uzyskanego przez dzieci w tym ćwiczeniu. W kolejnych odpowiednio: 50 - 75\% oraz 25 - 50\% najwyższego wyniku. W czwartym przedziale znalazły się wyniki uszeregowane od najniższego do 25\% rezultatu maksymalnego. Porównując uśrednioną ocenę arbitrów z wynikiem końcowym przyznawanym przez aplikację, możliwe było oszacowanie czułości i precyzji jej działania.

Ostatnim etapem procedury badawczej było przeprowadzenie po zakończeniu próby ruchowej wywiadu z badanymi dziećmi. Pytania zawarte w wywiadzie dawały odpowiedź na takie kwestie projektu, jak atrakcyjność zaprezentowanej aplikacji, jej ewentualnej przewagi nad tradycyjną formą ćwiczeń korekcyjnych, czy też jej wpływu na poziom motywacji uczniów do podejmowania czynności korekcyjnych.

\section{Charakterystyka grupy badawczej}

Badana grupa liczyła 28 uczniów, wśród których znalazło się 17 chłopców (ok. 60\% badanych) i 11 dziewczynek (ok. 40\% badanych). Pomimo pewnej przewagi chłopców pod względem liczebności przyjęto, iż takie zróżnicowanie grupy badawczej pod względem płci nie wpłynie na wynik eksperymentu. Natomiast, biorąc pod uwagę wiek badanych, najwięcej znalazło się wśród nich 9-latków (16 uczniów - 57\% badanych), następnie 8-latków (7 uczniów - 25\% badanych), najmniej zaś 10-latków (5 uczniów - 18\% badanych). Średni wiek uczniów wynosił 8,93 lat. Grupa okazała się zatem dość jednorodna pod względem wieku. Dane obrazujące wspomniane zróżnicowanie badanych zostały zawarte w tabeli 1 .

Tabela 1

Zróżnicowanie grupy badawczej pod względem wieku i płci

\begin{tabular}{|c|c|c|c|c|c|}
\hline \multicolumn{4}{|c|}{ WIEK } & \multicolumn{2}{c|}{ PŁEĆ } \\
\hline 8 lat & 9 lat & 10 lat & ŚREDNIA & CHŁOPCY & DZIEWCZĘTA \\
\hline 7 & 16 & 5 & 8,93 & 17 & 11 \\
\hline
\end{tabular}

Biorąc pod uwagę różnice pomiędzy dziećmi dotyczące wzrostu, to najniższy przebadany uczeń mierzył 124 cm, zaś najwyższy - 149 cm. Okazało 
się zatem, że dzieci znacznie różniły się pod względem wysokości ciała, co jest charakterystyczne dla tej grupy wiekowej. Uwzględniając jednak odniesienie do norm rozwojowych zawartych w siatce centylowej ${ }^{7}$, wyniki plasują grupę w średnich kanałach centylowych. $Z$ analizy wyników wykluczono jednak rezultaty dwojga 9-latków - dziewczynki o wzroście 149 cm i chłopca mierzącego $148 \mathrm{~cm}$, którzy pod względem wzrostu plasują się powyżej normy centylowej 97.

Tabela 2

Zróżnicowanie grupy badawczej pod względem wzrostu

\begin{tabular}{|c|c|c|c|c|}
\hline \multirow{2}{*}{ Wiek } & \multicolumn{2}{|c|}{ DZIEWCZETA } & \multicolumn{2}{c|}{ CHŁOPCY } \\
\cline { 2 - 5 } & średni wzrost & $\begin{array}{c}\text { poziom } \\
\text { centylowy }\end{array}$ & średni wzrost & $\begin{array}{c}\text { poziom } \\
\text { centylowy }\end{array}$ \\
\hline 8 & 131 & $50 c$ & 130 & $50 c$ \\
\hline 9 & 133 & 25-50c & 136 & $50 c$ \\
\hline 10 & 138 & $50 c$ & 139 & 25-50c \\
\hline
\end{tabular}

Z kolei, rozkład podgrup badanych zróżnicowanych pod względem wysokości ciała przedstawia rycina 1 , z której można odczytać, iż nie pojawiła się jedna, dominująca grupa w tym zakresie.

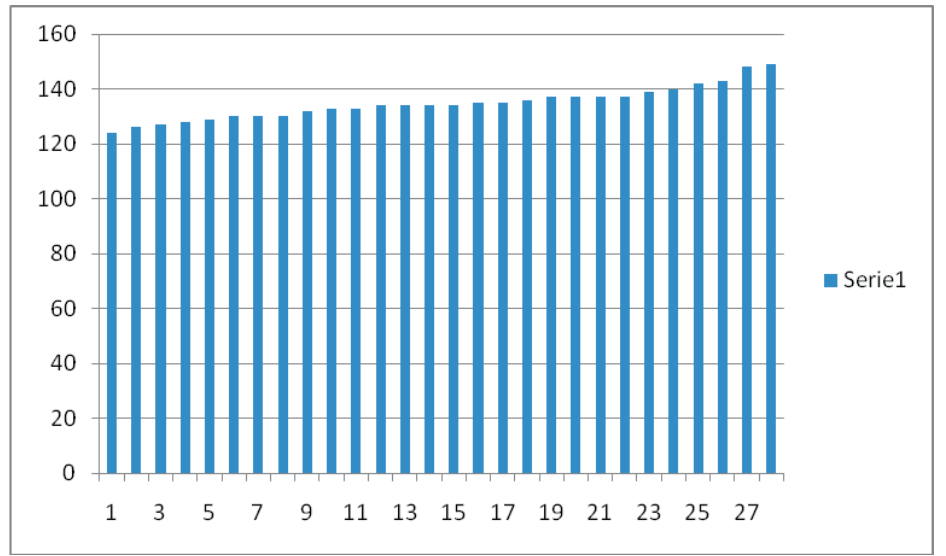

Ryc. 1. Zróżnicowanie badanej grupy pod względem wysokości ciała

Badana grupa wykazała także zróżnicowanie pod względem ciężaru ciała. Najniższy pomiar tej cechy morfologicznej wyniósł 22 kg, zaś najcięższy uczeń ważył $46 \mathrm{~kg}$. Podobnie zatem jak w przypadku wysokości ciała warto tak dużą różnorodność wyników odnieść do norm zawartych w siatce centylowej.

${ }^{7}$ I. Palczewska, Z. Niedźwiecka, Wskaźniki rozwoju somatycznego dzieci i młodzieży warszawskiej, Medycyna Wieku Rozwojowego, 20015, Supl. I, 2. 
Tabela 3

Zróżnicowanie grupy badawczej pod względem ciężaru ciała

\begin{tabular}{|c|c|c|c|c|}
\hline \multicolumn{3}{|c|}{ DZIEWCZĘTA } & \multicolumn{2}{c|}{ CHŁOPCY } \\
\hline Wiek & średnia waga & $\begin{array}{c}\text { poziom } \\
\text { centylowy }\end{array}$ & średnia waga & $\begin{array}{c}\text { poziom } \\
\text { centylowy }\end{array}$ \\
\hline 8 & 26 & $25-50 c$ & 26,8 & $25-50 c$ \\
\hline 9 & 28 & $25-50 c$ & 36 & $75 c$ \\
\hline 10 & 37 & $50-75 c$ & 31 & $25-50 c$ \\
\hline
\end{tabular}

Rycina 2 prezentuje rozkład liczebności badanych w grupach zróżnicowanych pod względem ciężaru ciała. Można z niego odczytać, iż także w tym przypadku badani wykazali zróżnicowanie oraz trudno wskazać jedną, dominującą w zakresie ciężaru ciała grupę.

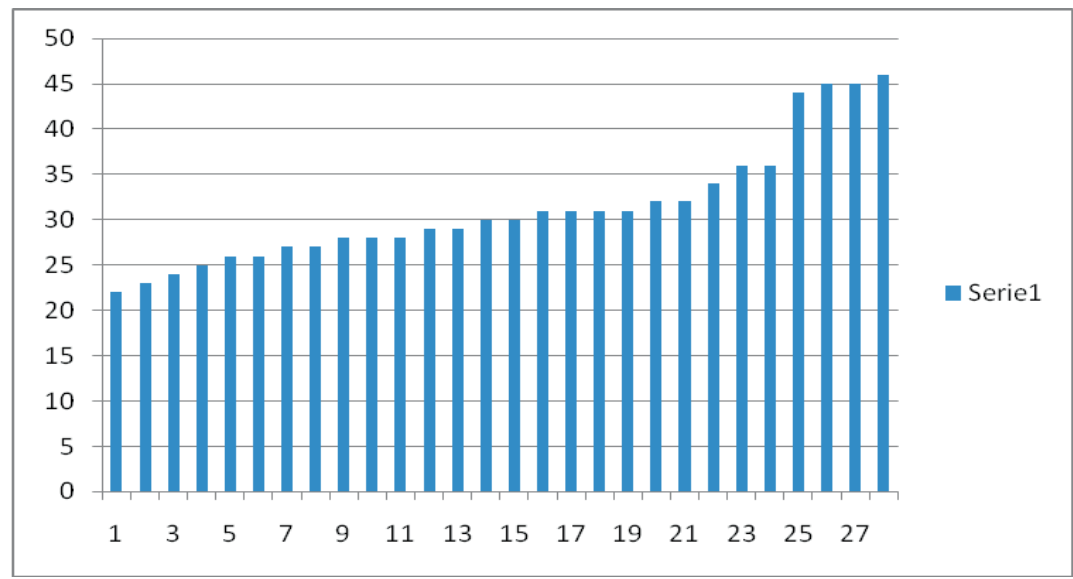

Ryc. 2. Zróżnicowanie badanej grupy pod względem ciężaru ciała

Z punktu widzenia projektu badawczego, najbardziej istotna jest jednak charakterystyka badanych uczniów uwzględniająca nieprawidłowości w ich budowie ciała. Analizując ten aspekt rozwojowy, należy zaznaczyć, że każdy przebadany uczeń (w całościowej ocenie sylwetki) wykazywał tendencję do pojawienia się wady określanej jako plecy okrągłe. Okazało się, że najczęściej występującym zaburzeniem jest nadmierne odstawanie łopatek, zaobserwowane aż u 22 badanych (78\%). Z kolei, u 16 uczniów zdiagnozowano znaczne wysunięcie barków do przodu (57\% badanych), a u 7 wysunięcie w przód głowy (25\%). Należy dodać, że jedynie u 4 uczniów zaobserwowano duże powiększenie kifozy piersiowej (14\% badanych). Może to świadczyć o początkowej fazie rozwoju tej wady postawy, co decyduje o większej skuteczności 
terapii i uzyskaniu trwałych efektów leczenia. Wykorzystane w badaniach ćwiczenia były w związku z tym ukierunkowane na eliminowanie stwierdzonych zaburzeń w prawidłowym obrazie sylwetki. Dane liczbowe obrazujące występowanie $\mathrm{u}$ badanych uczniów charakterystycznych elementów zaburzeń postawy przedstawia tabela 4.

Tabela 4

Występowanie w badanej grupie zaburzeń postawy ciała

\begin{tabular}{|l|c|c|c|}
\hline \multicolumn{1}{|c|}{ RODZAJ ZABURZENIA } & DZIEWCZĘTA & CHEOPCY & RAZEM \\
\hline Głowa wysunięta do przodu & 4 & 3 & $\mathbf{7}$ \\
\hline Barki wysunięte do przodu & 9 & 7 & $\mathbf{1 6}$ \\
\hline Odstawanie łopatek & 14 & 8 & $\mathbf{2 6}$ \\
\hline Wypukły brzuch & 8 & 2 & $\mathbf{1 0}$ \\
\hline Powiększona kifoza piersiowa & 2 & 2 & $\mathbf{4}$ \\
\hline Pogłębiona lordoza lędźwiowa & 5 & 5 & $\mathbf{1 0}$ \\
\hline Skolioza & 4 & 4 & $\mathbf{8}$ \\
\hline
\end{tabular}

Na podstawie przeprowadzonej charakterystyki badanych uczniów można wysunąć wnioski, że płeć badanych oraz zróżnicowanie pod względem wzrostu i wagi nie ma wpływu na wyniki badań. Obraz badanych pod względem nieprawidłowości budowy ciała pokazał, że każdy badany uczeń wykazywał cechy pleców okrągłych.

\section{Omówienie wyników badań i dyskusja}

W początkowej fazie próby ruchowej zapoznawano testowanych z przygotowanymi ćwiczeniami. Osoby oceniające korygowały ruchy badanych, wykorzystując słowne komendy lub bezpośrednio (z pomocą odczuć kinestetycznych) zmieniały sposób wykonywanego ćwiczenia. Następnie sprawdzano, czy poprawione ćwiczenie zostawało, przy ponownym wykonaniu, „nagrodzone" większą liczbą punktów. W ten sposób weryfikowano, czy aplikacja także "dostrzegła” przy pomocy czujnika Kinect nieprawidłowe wykonanie ćwiczenia, wychwytując pojawiające się błędy czy niedokładności rytmu, przyznając ćwiczącemu odpowiednio mniejszą liczbę punktów. Inaczej mówiąc, oceniano czułość aplikacji na błędy ćwiczącego. Procentowy rozkład wyników punktowych naliczanych przez aplikację zaprezentowano w tabeli 5 . 
Tabela 5

Procentowy rozkład wyników punktowych naliczanych przez aplikację w poszczególnych ćwiczeniach

\begin{tabular}{|c|c|c|c|c|c|c|c|c|c|c|c|c|}
\hline \multirow{3}{*}{$\begin{array}{c}\text { Przedziały } \\
\text { wyników } \\
\text { punktowych }\end{array}$} & \multicolumn{12}{|c|}{ Ćwiczenie } \\
\hline & \multicolumn{2}{|c|}{ marsz } & \multicolumn{2}{|c|}{ łokcie } & \multicolumn{2}{|c|}{ żabka } & \multicolumn{2}{|c|}{ wspinanie } & \multicolumn{2}{|c|}{ rozpiętki } & \multicolumn{2}{|c|}{ krążenia } \\
\hline & $\mathrm{N}$ & $\%$ & $\mathrm{~N}$ & $\%$ & $\mathrm{~N}$ & $\%$ & $\mathrm{~N}$ & $\%$ & $\mathrm{~N}$ & $\%$ & $\mathrm{~N}$ & $\%$ \\
\hline $\begin{array}{l}75 \% \text { Smax }- \\
\text { Smax }\end{array}$ & 11 & 39.3 & 9 & 32,1 & 12 & 42,8 & 9 & 32,1 & 8 & 28,6 & 13 & 46,4 \\
\hline $50-75 \%$ Smax & 7 & 25 & 10 & 35,7 & 8 & 28,6 & 8 & 28,6 & 9 & 32,1 & 8 & 28,6 \\
\hline $25-50 \%$ Smax & 8 & 28,6 & 6 & 21,4 & 3 & 10,7 & 6 & 21,4 & 7 & 25 & 5 & 17,8 \\
\hline $\begin{array}{ll}25 \% & \text { Smax } \\
\text { Smin } & \end{array}$ & 2 & 7,1 & 3 & 10,7 & 5 & 17,8 & 5 & 17,8 & 4 & 14,3 & 2 & 7,1 \\
\hline
\end{tabular}

Smax - (score maximum) maksymalny wynik punktowy.

Smin - (score minimum) minimalny wynik punktowy.

Zaobserwowano, że w ćwiczeniach, w których dominującym elementem były ruchy kończyn górnych (tzn. łokcie, rozpiętki i krążenia), oceny arbitrów korespondują ze wskazaniami czujnika ruchu. Natomiast w ćwiczeniach wykorzystujących także ruchy tułowia (tzn. marsz, żabka i wspinanie) dostrzeżono rozbieżności wskazań miernika aplikacji z ocenami arbitrów zarówno w obszarze dokładności, jak też rytmiki ruchów. Fakt ten może sugerować niedokładność pomiaru urządzenia, wynikającą z zastosowania nieodpowiedniego algorytmu. $\mathrm{W}$ tabeli 6 przedstawiono średnie oceny arbitrów w poszczególnych przedziałach punktowych oraz wskaźnik zgodności tych ocen z wynikiem uzyskanym przez ćwiczących w aplikacji (wskaźnik 1,00 oznacza całkowitą zgodność ocen arbitrów i aplikacji).

Średnie oceny arbitrów w poszczególnych przedziałach punktowych

\begin{tabular}{|c|l|c|c|c|}
\hline \multirow{4}{*}{ Ćwiczenie } & $\begin{array}{c}\text { Przedziały } \\
\text { wyników } \\
\text { punktowych }\end{array}$ & $\begin{array}{c}\text { Średnia ocen } \\
\text { precyzji wyko- } \\
\text { nania ruchu }\end{array}$ & $\begin{array}{c}\text { Średnia ocen } \\
\text { rytmu wykona- } \\
\text { nia ruchu }\end{array}$ & $\begin{array}{c}\text { Wskaźnik } \\
\text { zgodności ocen }\end{array}$ \\
\hline \multirow{5}{*}{ Marsz } & $75 \%$ - Smax & 7,3 & 7,5 & 0,74 \\
\cline { 2 - 5 } & $50-75 \%$ Smax & 8,1 & 7.9 & 0,68 \\
\cline { 2 - 5 } & $25-50 \%$ Smax & 8,3 & 7,3 & 0,69 \\
\cline { 2 - 5 } & $25 \%$ Smax - Smin & 6.1 & 5,8 & 0,67 \\
\hline \multirow{5}{*}{ Eokcie } & $75 \%-$ Smax & 8,8 & 8,9 & $\mathbf{0 , 9 3}$ \\
\cline { 2 - 5 } & $50-75 \%$ Smax & 7,3 & 8,3 & $\mathbf{0 , 9 3}$ \\
\cline { 2 - 5 } & $25-50 \%$ Smax & 7,4 & 8,1 & 0,91 \\
\cline { 2 - 5 } & $25 \%$ Smax - Smin & 6.3 & 6,1 & 0,92 \\
\hline \multirow{5}{*}{ Żabka } & $75 \%-$ Smax & 7,1 & 7,8 & 0,73 \\
\cline { 2 - 5 } & $50-75 \%$ Smax & 7,5 & 7,1 & 0,77 \\
\cline { 2 - 5 } & $25-50 \%$ Smax & 6,9 & 7,2 & 0,75 \\
\cline { 2 - 5 } & $25 \%$ Smax - Smin & 6,6 & 6,1 & \\
\hline
\end{tabular}




\begin{tabular}{|l|l|l|l|l|}
\hline \multirow{4}{*}{ Wspinanie } & $75 \%$ - Smax & 8,4 & 8,2 & 0,69 \\
\cline { 2 - 5 } & $50-75 \%$ Smax & 8,4 & 8,6 & 0,76 \\
\cline { 2 - 5 } & $25-50 \%$ Smax & 6.2 & 6,8 & 0,74 \\
\cline { 2 - 5 } & $25 \%$ Smax - Smin & 6,9 & 7,2 & 0,69 \\
\hline \multirow{5}{*}{ Rozpętki } & $75 \%$ - Smax & 8,6 & 8,4 & $\mathbf{0 , 9 5}$ \\
\cline { 2 - 5 } & $50-75 \%$ Smax & 8,2 & 8,2 & $\mathbf{0 , 8 9}$ \\
\cline { 2 - 5 } & $25-50 \%$ Smax & 7,6 & 7,6 & $\mathbf{0 , 9 0}$ \\
\cline { 2 - 5 } & $25 \%$ Smax - Smin & 6,9 & 7,3 & $\mathbf{0 , 9 1}$ \\
\hline \multirow{5}{*}{ Krążenia } & $75 \%$ - Smax & 9,1 & 8,8 & $\mathbf{0 , 9 7}$ \\
\cline { 2 - 5 } & $50-75 \%$ Smax & 7,9 & 7,9 & $\mathbf{0 , 9 7}$ \\
\cline { 2 - 5 } & $25-50 \%$ Smax & 7,2 & 6,9 & $\mathbf{0 , 9 7}$ \\
\cline { 2 - 5 } & $25 \%$ Smax - Smin & 7,1 & 7,0 & \\
\hline
\end{tabular}

Smax - (score maximum) maksymalny wynik punktowy

Smin - (score minimum) minimalny wynik punktowy

W końcowej części projektu przeprowadzono badanie ankietowe, w którym dzieci odpowiadały na 7 pytań odnośnie różnych aspektów zastosowania ćwiczeń z wykorzystaniem czujnika ruchu. Odpowiedzi sugerują, że taka forma ćwiczeń jest, zdaniem badanych, czynnikiem motywującym do samodzielnego podejmowania działań w obszarze korekcji wad postawy. Oceny poszczególnych elementów ćwiczeń pod kątem ich stopnia trudności czy atrakcyjności są zróżnicowane, co należy wziąć pod uwagę w ostatecznym kształcie (również graficznym) zaproponowanej gry. Szczegółowe odpowiedzi na pytania zawarte $\mathrm{w}$ kwestionariuszu ankiety zaprezentowano w tabeli 7.

Tabela 7

Zestawienie liczbowe i procentowe odpowiedzi na pytania ankiety

\begin{tabular}{|c|c|c|c|c|c|}
\hline & TREŚĆ & ODPO- & & NIKI & \\
\hline & PYTANIA & WIEDZI & $\mathrm{n}$ & $\%$ & UBRAZ GRAFILZNY \\
\hline 1 & $\begin{array}{l}\text { Czy uczęsz- } \\
\text { czasz na gim- } \\
\text { nastykę korek- } \\
\text { cyjną? }\end{array}$ & $\begin{array}{l}- \text { tak } \\
\text { - nie }\end{array}$ & $\begin{array}{l}12 \\
16\end{array}$ & $\begin{array}{l}42,86 \\
57,14\end{array}$ & \\
\hline 2 & $\begin{array}{l}\text { Czy miałeś } \\
\text { wcześniej kon- } \\
\text { takt z grami } \\
\text { interaktywny- } \\
\text { mi? }\end{array}$ & $\begin{array}{l}- \text { tak } \\
\text { - nie }\end{array}$ & $\begin{array}{r}24 \\
4\end{array}$ & $\begin{array}{l}85,71 \\
14,29\end{array}$ & \\
\hline
\end{tabular}




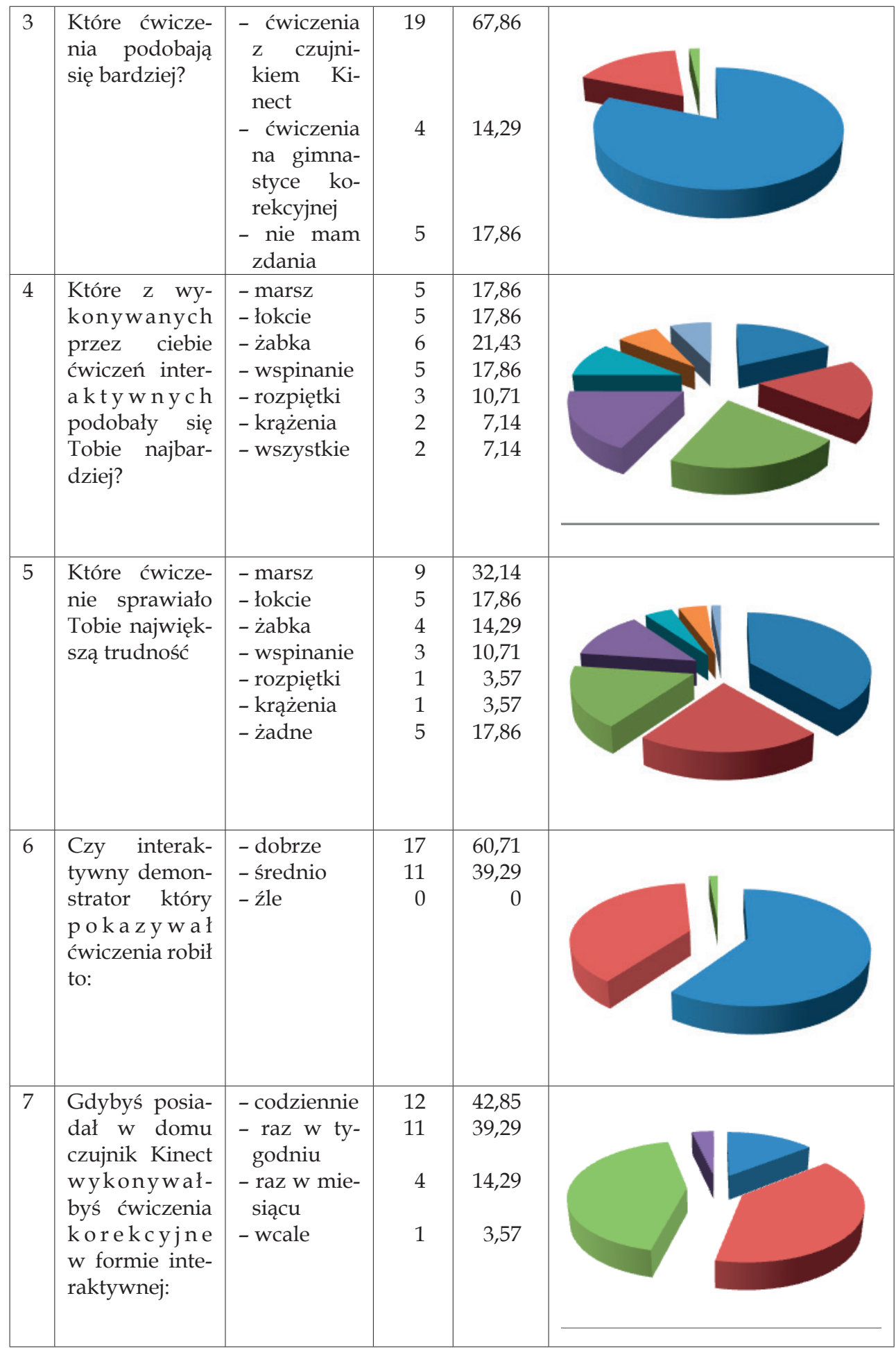




\section{Podsumowanie i wnioski}

Pierwsze wnioski, płynące z przeprowadzonego badania, można sformułować już po analizie grupy badawczej. Powszechne występowanie wśród badanych uczniów zaburzeń sylwetki o cechach wady pleców okrągłych potwierdziło słuszność założenia (hipotezy), że wada ta występuje w znacznym procencie u dzieci i celowe było przygotowanie aplikacji z ćwiczeniami korekcyjnymi dla tej konkretnej wady. Po drugie, jeżeli chodzi o etap testowania aplikacji przez uczniów, to badani starali się wykonywać ćwiczenia szybko, aby zmieścić się w przewidzianym czasie, nie zwracając koniecznej uwagi na jego dokładność. Należy zatem ustalić takie tempo ćwiczeń, które zapewniałoby komfort ćwiczącego i jego skupienie na precyzji ruchu. Po trzecie, punktacja za ćwiczenia generowana przez czujnik ruchu nie zawsze zgadzała się z poprawnością jego wykonania. Dotyczy to w szczególności tych ćwiczeń, w których zmienia się położenie tułowia. Należy zatem dopracować założenia zastosowanego algorytmu lub wprowadzić markery (np. umieszczane na ciele ćwiczących i rozpoznawane przez czujnik) w celu korekty zauważonych niedokładności. Warto podkreślić, że aplikacja ma duże możliwości upowszechnienia ćwiczeń korekcyjnych dla różnych wad postawy wśród dzieci, a graficzne przygotowanie jej w formie gry interaktywnej, z możliwością pokonywania kolejnych poziomów trudności, mobilizuje dzieci do pracy przez zabawę. Wniosek ten znajduje $\mathrm{z}$ kolei potwierdzenie $\mathrm{w}$ pozytywnej ocenie aplikacji przez uczniów. Uznali oni, że taka forma ćwiczeń jest znacznie atrakcyjniejsza od tradycyjnych ćwiczeń korekcyjnych. Prace nad projektem powinny być w związku z tym kontynuowane, z uwzględnieniem dotychczasowych uwag i wniosków.

\section{BIBLIOGRAFIA}

Barczyk K., Kształtowanie się krzywizn przednio-tylnych kręgostupa i asymetrii tułowia u dzieci w młodszym wieku szkolnym, rozprawa doktorska, AWF, Wrocław 2003.

Hagner W., Bąk D., Hagner-Derengowska M., Changes in body posture in children between the 10th and 13th years of age, Pol. Ann. Med., 2011, 18, 1.

Janiszewska R. i wsp., Nieprawidłowości postawy ciała u dzieci 6-12-letnich-uczniów szkót podstawowych z Radomia - badania pilotażowe, Probl. Hig. Epidemiol., 2009, 90(3).

Kania-Gudzio T., Wiernicka M., Ocena postawy ciała dzieci w wieku 7-15 lat na podstawie wybranej losowo szkoty podstawowej miasta Poznania, Now. Lek., 2002, 71, 2-3.

Kasperczyk T., Wady postawy ciata - diagnostyka i leczenie, Wydawnictwo Kasper, Kraków 2001.

Kopaniarz I.A., Przyczyny powstawania i korekta wad postawy, Lider, 2003, 4.

Mazur J. (red.), Zdrowie i zachowania zdrowotne młodzieży szkolnej w Polsce na tle wybranych uwarunkowań socjodemograficznych, Instytut Matki i Dziecka, Warszawa 2014. 
Mikołajewska E., Mikołajewski D., Wykorzystanie robotów rehabilitacyjnych do usprawniania, Niepełnosprawność - zagadnienia, problemy, rozwiązania, 2013, 4(9), 38.

Palczewska I., Niedźwiecka Z., Siatki centylowe do oceny rozwoju somatycznego dzieci i młodzieży, Instytut Matki i Dziecka, Warszawa 1999.

Palczewska I., Niedźwiecka Z., Wskaźniki rozwoju somatycznego dzieci i młodzieży warszawskiej, Medycyna Wieku Rozwojowego, 20015, Supl. I, 2.

Wen Li. i wsp., Characteristics of Internet Addiction/Pathological Internet Use in U.S. University Students: A Qualitative-Method Investigation, PLoS One, 2015, 10(2)

Wilczyński J., Korekcja wad postawy człowieka, Anthropos, Starachowice 2005.

Wojtyła A. i wsp., Aktywność fizyczna młodzieży gimnazjalnej w Polsce, Probl. Hig. Epidemiol., 2011, 92(2).

Yim J., Graham N.T.C., Using games to increase exercise motivation, [w:] Future Play '07: Proceedings of the 2007 conference on Future Play, ACM, Inc. Toronto 2007.

Zwierzchowska A., Gawlik K., Korektywa dzieci i młodzieży z dysfunkcjami wzroku lub stuchu, AWF, Katowice 2006.

www.Zdrowie 21.edu.pl 